UDC 641:613.2

DOI https://doi.org/10.32838/2663-5941/2019.6-2/17

\author{
Ditrikh I.V. \\ National University of Food Technologies
}

Niemirich $\boldsymbol{O} . \boldsymbol{V}$.
National University of Food Technologies

Havrysh A.V.

National University of Food Technologies

Ustymenko I.M.

National University of Food Technologies

Gumeniuk A.A.

National University of Food Technologies

\title{
PYRAMIDS AND PLATES OF NUTRITION
}

The article analyzes the role of nutrition in human life, the relationship of nutrition with the consequences for health, since healthy nutrition to date human development is in the form of a shadow. Preserving and maintaining the health of Ukrainians and preventing chronic diseases are only possible if the attitude to the diet and lifestyle in general is reviewed. According to the analysis, the basis of traditional diet should be a diet that includes natural and unrefined foods. Food moderation should be observed and the use refined foods, especially sweets and low-nutrition fats, should be restricted.

The experience of improvement and development of innovative principles nutrition, the solution of problems unbalanced nutrition by systematization of existing and acquired information on the example pyramids and plates of nutrition, which are constantly being improved and undergoing significant changes, is conducted. Based on many years of experience of world-class scientists, the substantiation of the expediency of establishing and implementing in the diet of the population of Ukraine rules and methods based on pyramids and plates of nutrition, taking into account a number of determining factors: climate, age, range of food products, characteristic of the country and its regions.

As Ukrainians nutrition culture and Ayurvedic nutrition knowledge are low and in shade, Ayurvedic plates are offered for three doshas. Each dosha has a distinct affinity for certain organs, and they tend to accumulate in certain places. Thus, you can determine the necessary nutrition and lifestyle by knowing each person their dosha.

The information provided by the authors may provide a new impetus for improving the nutrition of the population of Ukraine, as well as the pyramids and plates of nutrition.

Key words: food pyramid, nutrition plate, health-improving nutrition, ayurveda, ayurvedic food.

Introduction. Human is a very interesting and mysterious creature for himself. For many centuries, this secret mystery and genuine interest has pushed it forward, sometimes developing, sometimes degrading and distorting the image of a "homo sapiens", modifying the outlook, life, speech, preferences in food and clothing. Shelter, food, clothing, physical and mental health - a necessary foundation for the humane existence. As a result of the millennial transformations of mankind, the solid strength of the foundation is pushed back to the background, and as is well-known, the unreliable foundation - it's first a small cracks, then unclear distortions of the building, and in the end quite understandable logical finale with tragic consequences, roar, cloud of dust and alive buried frivolous ignoramuses. The modern lifestyle and nutrition of a person are the determining aspects of its existence. These aspects are three-dimensional, clearly and carefully interpreted, structure the causes and consequences of acquired disorders, pathologies, defects of the organism, modification of human health, which without interference is reflected in the efficiency, quality of life, on the elemental sense of conditional happiness and life satisfaction. In the modern world of knocked down landmarks, the forced development of innovative technologies, unreasonable over-expectations, uncontrollable desires and desires to make absolutely everything, being at the same time in several places, forgetting about quality, 
the result can be only disappointment, and after disappointment should come a conscious understanding of the importance of caring for your own health. This is one of the worst mischief of the present day and the near future. Attention to at least a diet should improve the health, without attracting drugs.

Conscious professional scientists, understanding the importance of nutrition, develop, improve diets, pyramids and dishes of nutrition, hoping that this way is likely to reach the target audience. They are called on by their own responsibility to improve the awareness of the population and raise the level of education in the aspects of nutrition.

The food pyramid (nutrition pyramid) is a graphical overview of the basic dietary recommendations of the composition of the diet, which allows not only to analyze but also to correct its. Products that make up the pyramid should be consumed daily, but in different quantities and proportions, depending on the type of pyramid and the principles of the location of products in it, there are a lot of them.

The concept of building a food pyramid is based on: the principles of healthy eating; national peculiarities of dishes; food consumption regulations; caloric content of the diet; physiological individual features of the human body; modern knowledge of nutritionology.

The purpose of the article is to conduct an analytical review of literature on existing models of food pyramids, plates and the development of plates according to ancient eastern oriental food concepts, namely Ayurveda.

Materials and methods of research. During the research, the methods of theoretical generalization, scientific induction and deduction, mathematical and structural analysis have been used, also the works of foreign and domestic scientists, which are devoted to the systematization of information about the pyramids and plates of nutrition of the past and present-day experience have been studied.

Results and discussion. The food pyramid is a purely Swedish invention. In 1972 Anna Britt Angsetter presented the idea of a triangular model "Good Food at Reasonable Prices", which is divided into three levels, describing the products placed on the importance for the person from below to up. The pyramid fulfilled its social function by overcoming the crisis in Swedish society [1, c. 15].

The following food pyramids were attempted by the United States in 1992, the main difference being the separation of the dominant position for dairy products. As the disadvantage of this model is the recommendation to consume 6-11 servings of bread, cereals, rice and pasta per day, which led to an increase in obesity, the United States Department of Agriculture (USDA), together with the Department of Health and Social Services (HHS), realizing mistakes, changed the previous version and offered in 2007 a food pyramid called MyPyramid for children, adults and the elderly.

The pyramid design is vertical colored stripes. Each color has a different size, displaying the amount of food needed for each group. Stairs serve as a reminder of the necessity and importance of daily physical activity.

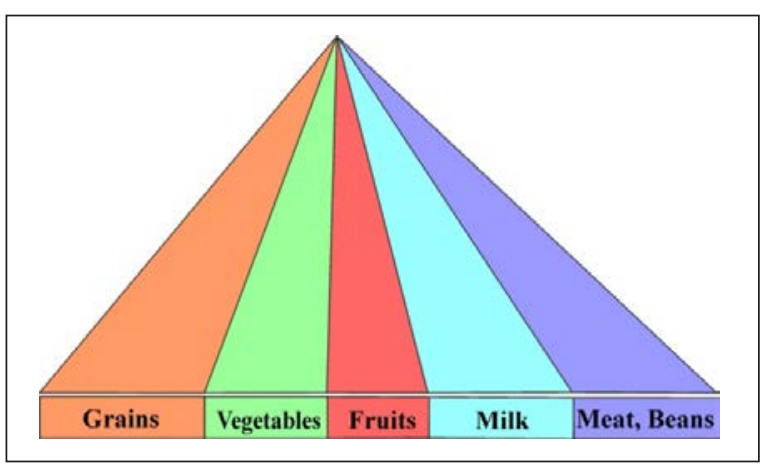

Fig. 1. "My Pyramid” 2007 (USA)

Nowadays, the trend of Asian food traditions has become widespread in the world. It should be noted that compared to the American-European version of the food pyramid, Asian is considered more useful because it contains local cereals, vegetables, fruits, green tea, nuts and bread, but it is characterized by a restriction of the consumption of meat, sweets, alcohol and especially dairy products, which are not assimilated by the body of East Asian inhabitants $[2$, c. $25 ; 3$, c. 16,18$]$.

It is hardly possible to find obsessive adherents of healthy eating as vegetarians. These people really consciously relate to their diet and life in general. Pyramid of nutrition for vegetarians depending on the type of vegetarianism (vegan and lacto-geriatricism), does not contain meat and/or dairy products, fish, eggs, because of which there is an increased need for iron, calcium, vitamins $\mathrm{B} 12$ and $\mathrm{D}$, which are consumed in the form of additives [4, c.165, 167].

Protein products of animal origin are replaced by vegetable products (tofu, beans, nuts). In scientific circles, the connoisseurs of vegetarianism refer to longer than "meat-eating" lives, rarer cardiovascular diseases, hypertension, diabetes and cancer of the rectum $[5$, c.1052, 1054; 6, c.1320]

Another attempt to bring the strip under the healthy nutrition of all humanity has tried the World Health Organization (WHO), having created a "Nutrition Pyramid on the recommendations of WHO", using a color scheme of a traffic light. It is based on the products necessary for healthy eating, the diversity and correlation that it illustrates [7, c.118, 125; 8, c.285] 
More than half of the daily energy should come from products that are part of the two lower green layers of the pyramid, namely: with bread, cereals, pasta, rice and potatoes.

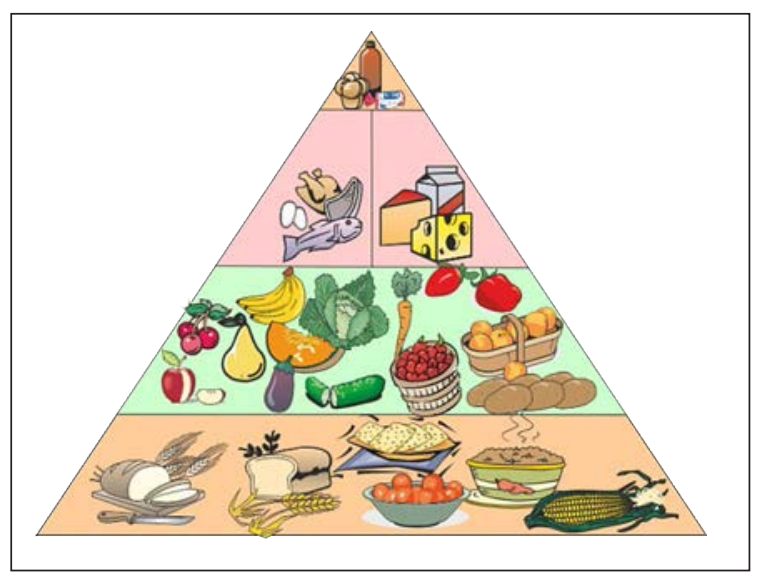

Fig. 2. Nutrition Pyramid on the recommendations of WHO

Each level color has its own meaning. Green consume without restrictions (not less than $400 \mathrm{~g}$.); yellow - consume cautiously; red - to think about whether to consume it. In 2011, in the United States, a new system of useful nutrition in the form of a plate called "My Plate" came to replace the food pyramids. The logo of the new healthy food system is in the form of a plate divided into four sectors: cereal products, fruits, vegetables, protein products (meat, fish, beans and nuts).

The first plate of healthy nutrition in Ukraine's history is designed to bring every Ukrainian to a healthy and balanced diet. The plate was approved by the Ministry of Health of Ukraine (MHU) and the Center for Public Health of MHU [9, c. 8, 10, 13]. Based on the practices of the leading countries of the world, experts made it clear and accessible.

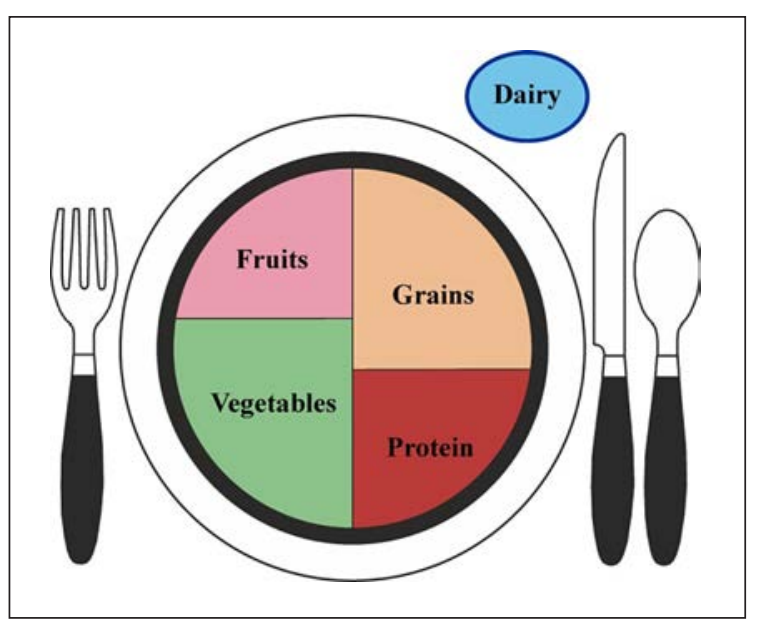

Fig. 3. «My Plate», 2011 (USA)

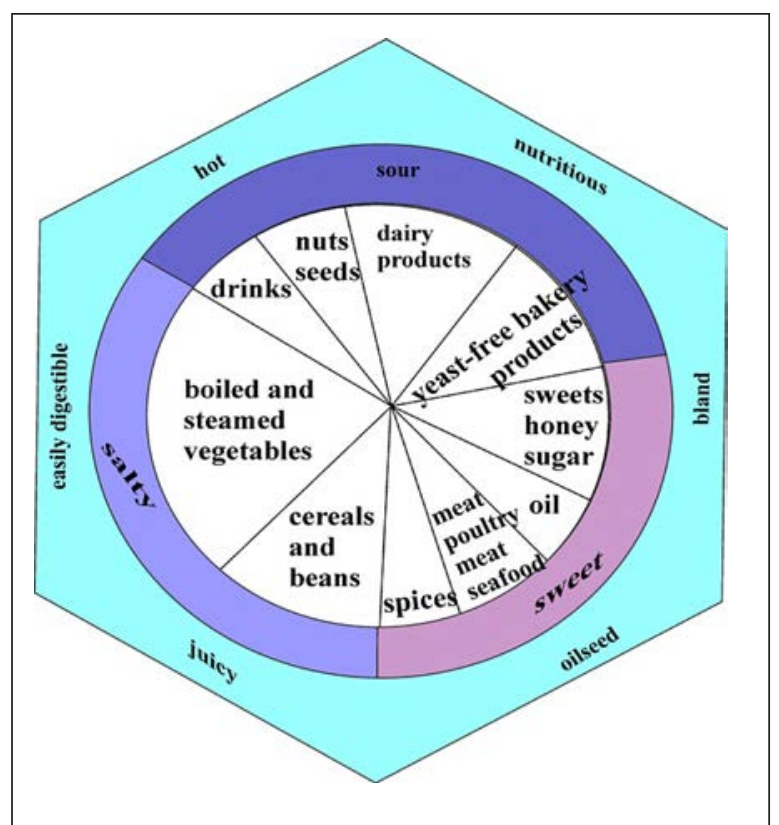

Fig.4. Plate of healthy nutrition, 2017 (Ukraine)

We note that the above models are an attempt to consider nutrition as a common template that can be applied to almost all, leaving out the need for an individual analysis of the peculiarities and needs of each unique organism.

Neglecting the value of calories, norms of consumption of fats, proteins, carbohydrates, vitamins, there are knowledge gained by humanity that may lead the prostrated materialists to the side of idealism. One of such knowledge is Ayurveda. On Ayurveda, all aspects and stages of the human way of life are considered as sacred. According to Ayurveda, every person is a unique phenomenon, and he is inseparable from space / environment. Everything that is in the macrocosm also exists in the microcosm. Every person is an embodiment of the manifestation of cosmic consciousness. None of the possible at the present time knowledge, except Ayurveda, is not capable of considering a person with a similar scale of comprehensiveness [10, c. 118, 121].

From the vibration of the pure world consciousness of the sound "Om" are created Five Great Elements - Ether, Air, Fire, Water and Earth. These Five Great Elements are manifested in the form of three biological beginnings - dosh: Vata, Pitta and Kapha, wich operate all processes in the organism, including pathological ones. At the time of the conception of any person, Vata, Pitta and Kapha determine the constitution of the person which is called "Prakriti" by their combinations and relations. "Prakriti" means "the first creation". Every human being is the "first creation" of the cosmos, which is why every person represents a separate essence, a unique phenomenon. 
On condition of knowledge of each person of his constitution, it becomes possible to determine the nutrition and lifestyle necessary for himself. Food, useful for one person, for another, will be a poison. Therefore, for a healthy, happy and harmonious life, you need to know your constitution. The constitution, depending on the number of dominant doshas happen to be: one-dosha, double-doshas (majority), triple-doshas [11].

Each dosha, in accordance with its inherent qualities, has a distinct affinity with certain organs of the body. All doshas are present in any cell, because life without them is impossible, but they tend to accumulate in certain places, which helps to determine of those who need attention by discomfort [12, c.222, 224]:

1. Vata dosha: brain, heart, large intestine, bones, lungs, bladder, bone marrow, nervous system.

2. Pitta dosha: skin, eyes, liver, brain, spleen, endocrine system, small intestine.

3. Kapha-dosha: brain, joints, oral cavity, lymph, stomach, pleural cavity, pericardial cavity.

Vata, Pitta and Kapha are necessary for life, but they can do much harm if they allow them to get out of harmony with each other. In what quantities your body produces each of the doshas, depends predominantly on which of the Six Tastes prevails in your diet. Six Tastes, as well as three doshas, are derived from the Five Great Elements, and each one helps maintain a balance of doshas, performing important functions in an organism. These Six Taste are Sweet, Sour, Salt, Pungent, Bitter and Astringent.

Sweet taste is formed from Earth and Water, Sweet taste strengthens Kapha, weakens Pitta and Vata. It nourishes and invigorates body and mind, satisfies hunger and thirst, promotes the growth of all tissues; abuse leads to obesity, diabetes, drowsiness, parasites, complicated blood circulation, eye inflammation, digestive disorders, vomiting, gases, apathy, stagnant phenomena in respiratory tracts and other disturbances as Kapha type.

Sour taste is formed from Earth and Fire, Sour taste strengthens Kapha and Pitta, weakens Vata. It strengthens and refreshes the organism, promotes the removal of waste, reduces spasm and tremor, improves appetite and digestion; abuse leads to feeling of bitterness, itching, dizziness, premature aging, body lethargy, inflammation.

Salty taste is formed from Water and Fire, Salty taste strengthens Kapha and Pitta, weakens Vata. It removes waste and cleanses the body, increases digestive ability and appetite, softens and relaxes the tissues; abuse leads to inflammation, edema, predisposition to bleeding, skin diseases, herpes and urticaria, joint disease, impotence, early wrinkles, early baldness [13, c.11, 26].
Pungent taste is formed from Fire and Air, Sharp taste strengthens Pitta and Vata, weakens Kapha. It wash away from the body secret secretion of all kinds, improves appetite; abuse leads to dizziness, fainting, dry mouth, tremor, weakness, exhaustion, feeling burning, fever, thirst, decreased secretion of the sexual glands.

Bitter taste is formed from Air and Ether, Bitter taste strengthens Vata, weakens Pitta and Kapha. It cleans and dry all selection, reduces sexual excitement and harmonizes the organism, turning all the tastes to a normal state of equilibrium. It increases appetite and prevents skin diseases and fever; abuse leads to all disorder associated with Vata, including numbness, exhaustion, cramping pain, rash, dizziness, headache, rigidity, tremor, decreased secretion of the gonads.

Astringent taste is formed from Air and Earth, Astringent taste strengthens Vata, weakens Pitta and Kapha. It heals, cleans and pulls all parts of the body, reduces the amount of secretions and reduces sexual arousal; abuse leads to all the violations associated with Vata, including tremor, seizures, constipation, dryness of the body, stretching, numbness with tingling, exhaustion, thirst, decreased secretion of the sexual glands [14, c. 84$]$.

All food consumed affects both the mind and the body. The mind has three possible states $[15$, c. 911$]$ :

Sattva, or equilibrium, is a normal state of mind in which it correctly recognizes;

Rajas, or motion, is a state in which excessive mental activity weakens the ability to recognize;

Tamas, or inertia, is a state in which insufficient psychic activity weakens the ability to recognize.

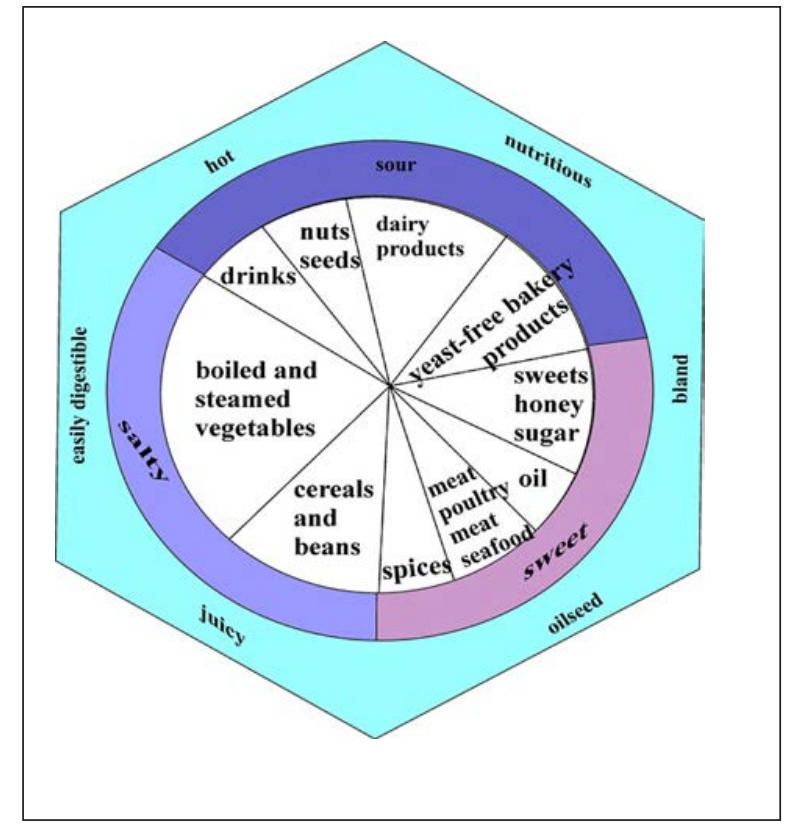

Fig. 5. Plate of nutrition for Vata Dosha 
Plates of nutrition for dash represent a indicative model of food, consisting of three levels. Food that is spoiled or unpleasant to taste, which was subjected to the process of fermentation, as alcohol, or persisted for a very long time, contributes to Tamas. Beans and other high protein products, such as meat, fish and poultry, as well as spicy spices strengthen Rajas. Rajas and Tamas violate the integrity of mind-body-spirit. Sattva, which promotes this integrity, is enhanced by the use of sweet foods - such as cereals and fruits, some vegetables and dairy products $[16$, c. 58$]$.

Using the model of a food plate, It is possible to illustrate the recommendations that calm the dosha. The first level - the characteristics of the cooked dish, the second level - the characteristics of the ingredients tastes required for cooking, the third level - the approximate ratio, the list and the possibility of using the products needed for each dosha.

Sweet, Sour and Salt food is good for people of Vata type, because it satisfies the body and reduces the likelihood of insufficient saturation. The bitter, pungent and astringent food is less useful because it dries the organism and increases emotional instability, especially uncertainty. No taste should be consumed in large quantities, because of abuses, Vata is violated.

People of Pitta type should not use sour, pungent, salty, but pay attention to the such tastes as: sweet, bitter and astringent. Meat, eggs, alcohol and salt reinforce natural aggressiveness of Pitta and its propensity to violence. Cereals, fruits and vegetables cool the heat of Pitta and should make up most of the diet for people of this type. Especially, for these people useful vegetarianism $[14$, c. 84$]$.

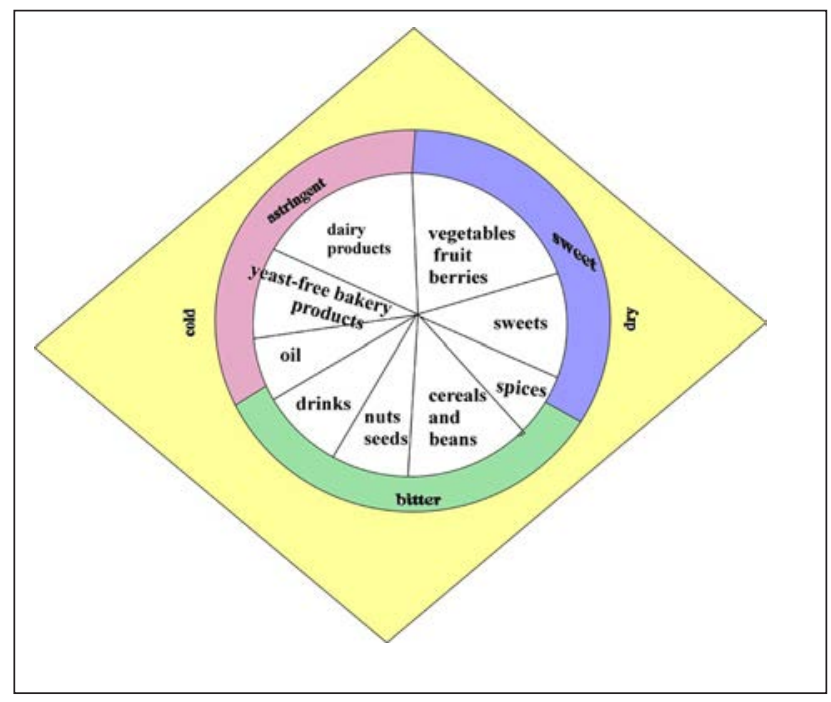

Fig. 6. Plate of nutrition for Pitta Dosha

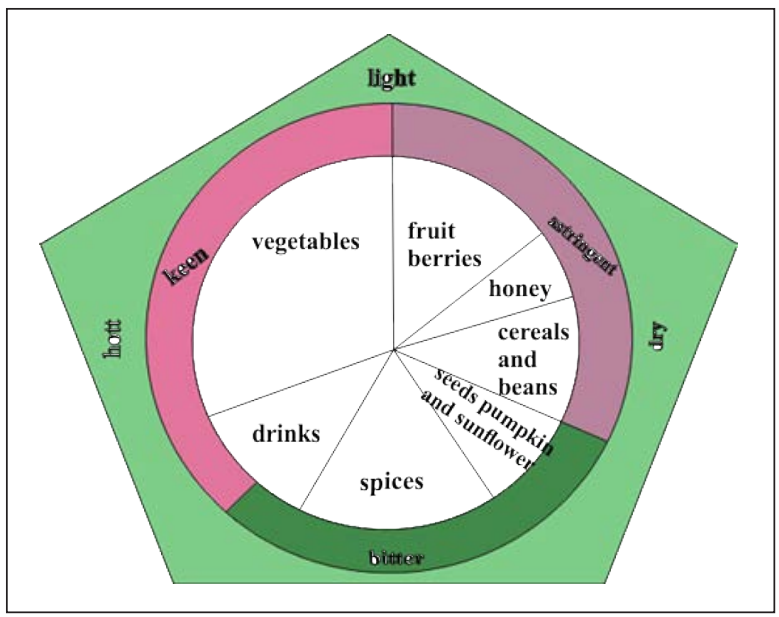

Fig. 7. Plate of nutrition for Kapha Dosha

People of the Kapha type should give preference to the bitter, pungent and astringent food that strengthens the body and the psyche, and avoid the consumption of sweet, sour and salty substances. In no case it is not possible to eat fried or any other fatty foods; dairy consumption should also be avoided. Fat is the worst food out of the possible. The best is vegetables. In general, people of this type should limit the total amount of food consumed [15, c. 911].

Conclusions. According to the above information, one can conclude that a really useful nutrition at this stage of development of mankind is in the form of a shadow, unpopular to the general population of the practice and requires a constant thorough interpretation of the importance of nutrition and its inevitable health effects. Improving the quality of life is a comprehensive approach to all spheres of life. Nutrition is one of these areas. Health savings, prevention of chronic diseases of Ukrainians is possible only in the case of viewing Ukrainians' attitudes towards nutrition and the way of their own life as a whole. When choosing foods, the preference must be given to natural, traditional foods that are the basis of the traditional nutrition of the population, to adhere to moderation in food, to restrict the use of refined products, especially sweets and low-quality fats. To help this important issue, pyramids and plates of nutrition are called, based on the many years of experience of world-class scientists, which should be listened to because they are trying to make the world better, at least most of them, and the foundation of its population is stronger, more reliable and healthier, you need only helping them, coming up, demonstrating with their inspirational desires and examples that changes are possible. Therefore, it is likely that in the near future, revived ancient teachings in the form of Ayurveda will receive a new impetus for popularity and development. 
Prospects for further research. Using, attracting pyramids and plates of nutrition to the diet of the population is a topical issue, as the culture of nutrition at the moment is at a low level, and very similar informative models, such as Ayurvedic plates for three doshas, are called to change it. Since Ayurvedic knowledge of nutrition is in the shadow and is not perceived by the academic community, a deep, comprehensive study of the doctrine should be introduced that will definitely become destitute or convinced of its importance.

\section{References:}

1. Walter P., Infanger E. Food Pyramid of the Swiss Society for Nutrition. Annals of Nutrition and Metabolism. 2007. № 2. P. 15-20.

2. Смоляр В.І. Типологія харчування. Проблеми харчування. 2006. № 1. С. 24-30.

3. Смоляр В.І. Еволюція європейського харчування. Проблеми харчування. 2004. № 1. С. 15-21.

4. Nakamoto K. A New Japanese Vegetarian Food Guide. Asia-Pacific Journal of Public Health. 2009. № 2. P. $160-169$.

5. Venti C.A, Johnston C.S. Modified food guide pyramid for lactovegetarians and vegans. J Nutr. 2002. № 132. P. 1050-1054.

6. Clarys P. Comparison of nutritional quality of the vegan, vegetarian, semi-vegetarian, pesco-vegetarian and omnivorous diet. Nutrients. 2014. № 3. P. 1318-1332.

7. Fowels E.R., Gabrielson M. First trimester predictors of diet and birth outcomes in low-income pregnant women. J Community Health Nurs. 2005. № 22. P. 117-130.

8. Bojar I. Change in the quality of diet during pregnancy in comparison with WHO and EU recommendationsenvironmental and sociodemographic conditions. Ann Agric Environ Med. 2006. № 13. P. 281-286.

9. Рекомендації щодо здорового харчування дорослих. 2017. МОЗ України, 20 с.

10. Сімахіна Г.О., Науменко Н.В. Харчування як основна складова системи оздоровлення: точки зору Аюрведи і вітчизняної нутриціології. Наукові праці Наџіонального університету харчових технологій. 2016. № 6. C. 117-125.

11. Singh M., Sharma T. Proposal for Exploring Possibilities for Finger Photoplethysmography as a Substitute for Pulse Diagnosis in Ayurveda. International Journal of Computer Science and Communication. 2012. № 2 (in press).

12. Hankey A. The Scientific Value of Ayurveda. The Journal of Alternative and Complementary Medicine Vol. 2005. № 2. P. 221-225.

13. Jayasundar, R., Quantum physics, ayurveda and spirituality. In Science and Spiritual Quest, Bhaktivedanta Institute, Kolkata, India. 2008. P. 11-28.

14. Singh M., Sharma T. Finger pulse plethysmograph feature selection for pitta detection in human body. IJCSC. 2012. № 1. P. 83-84.

15. Jayasundar R. Ayurveda: a distinctive approach to health and disease. Current Science. 2010. № 7. P. 908-914.

16. Payyappallimana U., Venkatasubramanian P. Exploring Ayurvedic Knowledge on Food and Health for Providing Innovative Solutions to Contemporary Healthcare. Front Public Health. 2016. № 4. 57-59.

\section{Дітрих І.В., Нсміріч О.В., Гавриш А.В., Устименко І.М., Гуменюк А.А. ПІРАМІДИ ТА ТАРІЛКИ ХАРЧУВАННЯ}

У статті проаналізовано роль харчування в життєдіяльності людини, взаємозв'язок харчування з наслідками для здоров'я, оскільки здорове харчування на нинішньому етапі розвитку людства знаходиться у формі тіні. Збереження та підтримання здоров'я українців та профілактика хронічних захворювань можливі лише у випадку перегляду ставлення до раціону харчування та способу власного життя виілому. Згідно з аналізом основою традииійного харчування населення повинен бути раціон, який включає натуральну та нерафіновану їжу. Необхідно дотримуватись помірності в їжі та обмеження вживання рафінованих продуктів харчування, в першу чергу солодощів та жирів низької харчової иінності.

Проведено аналіз досвіду вдосконалення та розвитку інноващійних принщипів харчування, вирішення проблем незбалансованого харчування шляхом систематизації наявної та набутої інформації на прикладі пірамід та тарілок харчування, які постійно вдосконалюються та зазнають суттевих змін. Виходячи з багаторічного досвіду вчених світового класу надано обтрунтування доиільності встановлення та впровадження до раџіону населення Украӥни правил та методів, заснованих на пірамідах 
та тарілках харчування з урахуванням ряду визначальних факторів, таких як: клімат, вік населення, асортимент харчових продуктів, характерний для країни та ї̈ регіонів.

Оскільки культура харчування украӥнців та аюрведичні знання про харчування знаходяться на низькому рівні та в тіні, запропоновано аюрведичні тарілки за трьома дошами. Кожна доша має виразну спорідненість із певними органами людини, і вони, як правило, накопичуються в певних місиях. Таким чином, можна визначити необхідне для себе харчування та спосіб життя залежно від конституції людини.

Запропонована авторами інформачія надасть нового поштовху для поліпшення харчування населення України через піраміди та тарілки харчування.

Ключові слова: харчова піраміда, тарілка харчування, оздоровче харчування, аюрведа, аюрведична їжа. 